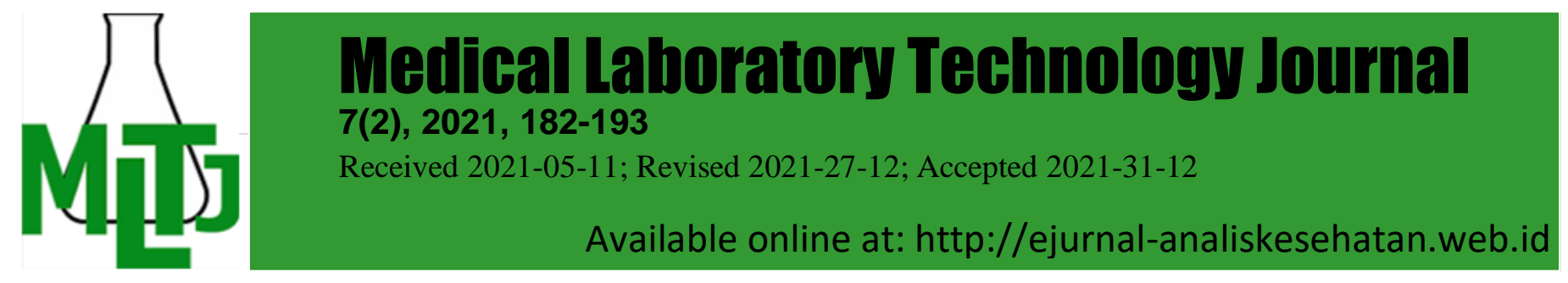

\title{
Immune Response to anti-HBs Antibodies in Health Workers Following Hepatitis B Vaccination
}

\author{
*Dinna Rakhmina, Wahdah Norsiah, Tini Elyn Herlina, Norhafizah Mulia Sari, \\ Reza Pertiwi, Rizka Ariani, Sahri Rahman
}

Medical Laboratory Technology Department, Poltekkes Kemenkes Banjarmasin, Indonesia. *Email: dinnapoltekesbjm@gmail.com

DOI: $10.31964 / \mathrm{mltj} . v 7 \mathrm{i} 2.418$

\begin{abstract}
According to Regulation No. 53 of 2015 of the Minister of Health of the Republic of Indonesia, a high risk of HBV infection in health workers is a problem that requires attention, and vaccination knowledge is critical to reducing these risk factors. Furthermore, because some people do not produce a sufficient antibody-forming (anti$\mathrm{HBs}$ ) response to $\mathrm{HBsAg}$, testing for evidence of protective immunity against hepatitis $B$ vaccination is required (Hepatitis B Surface Antigen). The purpose of the study was to determine the mapping of the characteristics of anti-HBs antibodies response after hepatitis $B$ vaccination in health workers in terms of age, gender, ethnicity, smoking habits, obesity, vaccination frequency, last time of vaccination. Sixty vaccinated health workers were used to creating the research sample. Anti-HBs levels/titers in serum were measured using the Enzyme-Linked Immunosorbent Assay (ELISA) method, and a questionnaire was used to compile the data for this study. Age, gender, smoking, obesity, and vaccination dose were all used to map the outcomes of the anti-HBs antibody immune response study. Anti-HBs antibody response in health workers was graded as poor in 36 people (60\%) and strong in 24 (40\%). Regarding ethnic origin, lifestyle, obesity, and vaccination dose (frequency), there was no significant link between post-vaccination anti-HBs antibody response in health workers. In terms of age and gender, there is a strong association between post-vaccination anti-HBs antibody responses in health workers. Low antibody titers should be revaccinated to enhance anti-HBs titers, and health workers who smoke should quit because it reduces the levels of anti-HBs titers produced clinically.
\end{abstract}

Keywords: vaccination; anti-HBs; health workers

\section{INTRODUCTION}

Hepatitis $B$ is a chronic or acute inflammatory liver disease caused by the Hepatitis B Virus (HBV). Hepatitis B is difficult to detect because the symptoms do not present right away, and some do not appear at all. As a result, many people are unaware that they have been infected. From exposure to the virus until the first symptoms show, this virus typically takes 1-6 months to develop (Chaurasia R, 2009; Levinson W, 2014; Yulia, 2019).

In $2013,1.2 \%$ of Indonesians had hepatitis, up from $0.6 \%$ in 2007 . Hepatitis B (21.8\%), hepatitis A (19.3\%), and hepatitis C are the hepatitis kinds that infect the Indonesian population (2.5\%). Given the scope of the problem and its implications for public health, coordinated, targeted, and widespread measures are required to combat the hepatitis virus outbreak (Pusdatin Kemenkes RI, 2017; Kemenkes RI, 2019).

Health workers are a high-risk group for hepatitis B infection, according to the Minister of Health of the Republic of Indonesia's Regulation No. 53 of 2015 concerning 
the control of viral hepatitis. Professionals related to health services are vulnerable to direct contact with the patient's blood and body fluids. HBV can be transmitted through contact with infected blood or body fluids and damage from contaminated sharp items such as needles. Health workers are four times more likely than the general population to get Hepatitis $B$ infection due to regular contact with patient's blood and body fluids (Kemenkes Rl, 2015).

Unvaccinated people have a $6-30 \%$ chance of contracting Hepatitis B after a single exposure. According to the $\mathrm{WHO}$, over 66,000 health workers worldwide are exposed to blood-borne HBV infections every year. Suppose a health worker is infected by mistake. In that case, there is a $1 \%$ chance of developing fulminant hepatitis, a $4 \%$ chance of developing chronic (active) hepatitis, and a $5 \%$ chance of becoming a virus carrier (Sahana et al., 2017). According to Roggendorf \& Viazov (2003), health workers are infected with HBV at a high incidence, with $5-10 \%$ of infected people being chronic HBV carriers. In circumstances of direct blood contact, such as surgery, hemodialysis units, or oncology wards, HBV transmission is widespread. Vaccination can also prevent HBV spread from patients to health workers.

The high risk of HBV infection among health care professionals is a problem that must be addressed, and vaccination knowledge is critical in reducing these risk factors. HBV infection can be prevented with vaccination. Furthermore, because some people do not produce a sufficient antibody-forming (anti-HBs) response to $\mathrm{HBsAg}$, testing for evidence of protective immunity against hepatitis $B$ vaccination is required (Hepatitis B Surface Antigen). According to field observations, few health workers still do not perform a response test for the production of anti-HBs after vaccinating for hepatitis B to establish post-vaccination antibody titers. Because data from this test will be used to determine whether the anti-HBs produced effectively protect against hepatitis B infection. After immunization, an anti-HBs titer of $>10 \mathrm{mlU} / \mathrm{ml}$ is considered an immunological marker that confers protection against infection (Zuckerman et al., 1997).

A study has shown that $10.5 \%$ of all successfully vaccinated people have not achieved a minimum level of antibody protection of $10 \mathrm{mlU} / \mathrm{ml}, 10.5 \%$ have antibody levels in the $11-100 \mathrm{mlU} / \mathrm{ml}$ range, $79 \%$ have antibody levels $>101 \mathrm{mlU}$. $/ \mathrm{ml}$ (Rao, S \& Sathiavathy., 2008). Another study conducted on 112 health workers showed that the level of protective antibodies was $99.9 \%$ after one year of vaccination and decreased to $80.96 \%$ and $46.16 \%$ after 5 and 10 years of vaccination (Mahawal et al., 2013). According to Tripathy et al. (2011), the immune response to vaccination is influenced by several factors, including age, gender, obesity, smoking, immunity, and genetic factors. In this study, the immune response of antibody formation after hepatitis B vaccination was associated with sex, age, ethnicity, smoking habits, body mass index leading to obesity, vaccination dose, and time of last vaccination.

Based on data from the Banjarbaru and Banjar Health Offices in 2019, which had conducted HBsAg tests on health workers in the region. The examination results found that one health worker had reactive $\mathrm{HBsAg}$, and only about $24 \%$ of health workers had been vaccinated against hepatitis B. In addition, of all the health workers who had been vaccinated, it turned out that they had never tested for anti-HBs antibodies. Therefore, based on this case, the study followed up on anti-HBs examination after hepatitis B vaccination in terms of age, sex, smoking, obesity, and frequency of vaccination to health workers. The data obtained from this study will be aimed at mapping the strong response and weak response to the formation of antiHBs antibodies after hepatitis B vaccination in terms of age, gender, smoking habits, obesity, vaccine dose, and last time of vaccination. 


\section{MATERIALS AND METHODS}

An analytic survey with a cross-sectional study design was used in this investigation. The sample used in this study was serum from health workers in Banjar and Banjarbaru district and students of Poltekkes Kemenkes Banjarmasin. They had been vaccinated with hepatitis $B$, with up to 60 samples collected using consecutive sampling techniques within a certain period. This research has been submitted to the Ethics Commission with the reference number 011/KEPK-RSDI/VII/2021 at Health Research Ethics Committee Idaman District Hospital of Banjarbaru.

Respondents vaccinated against hepatitis B were given informed consent, filled out a questionnaire, and collected three ccs of venous blood to check the antiHBs antibody titer using the ELISA (Enzyme-Linked Immunosorbent Assay) method, namely ELISA Reader with Zenix brand specifications. The results of the antibody titer examination were then mapped according to the characteristics of the respondents in terms of several aspects such as age, gender, smoking, obesity, vaccination dose, duration of the vaccine. In addition, the mapping of respondents' characteristics from the results of laboratory tests on anti-HBs titers was divided into two titer levels: $<100$ $\mathrm{mIU} / \mathrm{mL}$ as a weak antibody response and $100 \mathrm{mIU} / \mathrm{mL}$ as a strong antibody response. The data that has been collected is then processed using the standard statistical software. Data related to respondent characteristics such as age, gender, smoking, obesity, vaccination dose, last duration of vaccine, and data on anti-HBs test results will be described and displayed in tables and diagrams. Data processing used a Chisquare test to determine the significance of the relationship between age, gender, smoking, obesity, vaccination dose, duration of the last vaccine against anti-HBs titer formation. A significant relationship was obtained when the $p$-value $<0.05$.

\section{RESULTS AND DISCUSSION \\ Anti-HBs Antibody Response Status}

The results of an antibody titer examination utilizing the ELISA method were used to determine the anti-HBs antibody response. The antibody titers were divided into two groups: a weak response $(100 \mathrm{mIU} / \mathrm{mL})$ including 36 people $(60 \%)$ and a strong response $(100 \mathrm{mlU} / \mathrm{mL})$ involving 24 people $(40 \%)$.

Table 1. Anti-HBs Antibody Response Status

\begin{tabular}{lll}
\hline \multicolumn{1}{c}{ Variable } & $\mathbf{N}$ & $(\%)$ \\
\hline Weak Response $(<100 \mathrm{mlU} / \mathrm{mL})$ & $\mathbf{3 6}$ & $\mathbf{6 0}$ \\
Strong Response $(\geq 100 \mathrm{mlU} / \mathrm{mL})$ & $\mathbf{2 4}$ & $\mathbf{4 0}$ \\
\hline
\end{tabular}

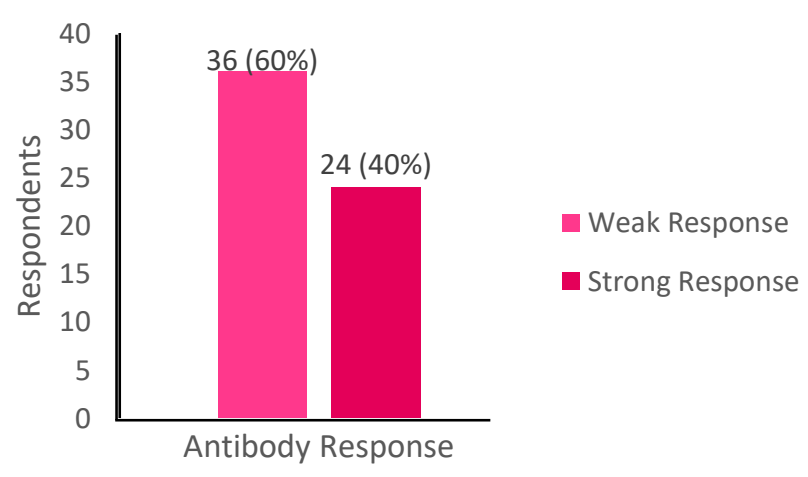

Figure 1. Anti-HBs Antibody Response 


\section{Anti-HBs Antibody Response after Vaccination and Respondents' Characteristics}

The table above shows the results of data analysis using Chi-Square (table 2). The group connected to gender, age, and last time of vaccination had a significance value of 0.005 . In contrast, the group associated with ethnicity, BMI, smoking habit, vaccination frequency, and disease history had a P-value $>0.005$.

Although statistically, there was no association between weak and firm responses to the development of anti-HBs antibodies and characteristics such as ethnicity, BMI, smoking habits, vaccination frequency, and disease history, clinically, it had importance. Due to the unequal distribution of the number of participants in each group, the statistics are useless. This can be shown in several ways, one of which is the respondents' smoking habits, where it was discovered that all respondents who smoked (7 people) had an inadequate response to the development of anti-HBs antibodies, despite having been vaccinated recently (within the last $1-5$ years).

Table 2. Anti-HBs Antibody Response Based on Respondent Status

\begin{tabular}{|c|c|c|c|c|c|}
\hline \multirow[t]{2}{*}{ Characteristics } & \multicolumn{2}{|c|}{$\begin{array}{c}\text { Weak } \\
\text { Response }\end{array}$} & \multicolumn{2}{|c|}{$\begin{array}{c}\text { Strong } \\
\text { Response }\end{array}$} & \multirow[t]{2}{*}{ P-Value } \\
\hline & $\mathbf{N}$ & $\%$ & $\mathbf{N}$ & $\%$ & \\
\hline Gender & & & & & 0,001 \\
\hline • Men & 20 & 91 & 2 & 9 & \\
\hline - Women & 16 & 42,1 & 22 & 57,9 & \\
\hline Age & & & & & 0,001 \\
\hline - $17-25$ & 25 & 80,6 & 6 & 19,4 & \\
\hline - $26-45$ & 8 & 34,8 & 15 & 65,2 & \\
\hline - $46-65$ & 3 & 50 & 3 & 50 & \\
\hline Ethnic & & & & & 0,956 \\
\hline - Banjar & 24 & 61,5 & 15 & 38,5 & \\
\hline - Non - Banjar & 12 & 57,1 & 9 & 42,9 & \\
\hline Body Mass Index & & & & & 0.058 \\
\hline - $<25 \mathrm{~kg} / \mathrm{m} 2($ Non - Obese) & 29 & 69 & 13 & 31 & \\
\hline$\geq 25 \mathrm{~kg} / \mathrm{m} 2$ (Obese) & 7 & 38,9 & 11 & 61,1 & \\
\hline Smoking & & & & & 0,059 \\
\hline • Smoking & 7 & 100 & 0 & 0 & \\
\hline $\begin{array}{l}\text { - Non - Smoking } \\
\text { Vaccination Frequency (Times) }\end{array}$ & 29 & 54,7 & 24 & 45,3 & 0,878 \\
\hline - 1 & 1 & 100 & 0 & 0 & \\
\hline - 2 & 4 & 57,1 & 3 & 42,9 & \\
\hline$\cdot 3$ & 31 & 59,6 & 21 & 40,4 & \\
\hline Last Vaccination Time (Years) & & & & & 0,003 \\
\hline$\cdot 0-5$ & 18 & 80 & 20 & 20 & \\
\hline - $5-10$ & 1 & 33,3 & 2 & 66,7 & \\
\hline - $10-20$ & 17 & 89,5 & 2 & 10,5 & \\
\hline Disease History & & & & & 0,492 \\
\hline - Yes & 14 & 50 & 14 & 50 & \\
\hline - No & 21 & 65,6 & 11 & 34,4 & \\
\hline
\end{tabular}




\section{Association of Anti-HBs Antibody Response and Gender}

Based on the data in table 2, it can be seen that the antibody response and gender have a significant relationship (P-value 0.005). A solid response to the formation of anti-HBs antibodies is more common in women (57.9\%), while a weak response is more common in men (91\%). The results of this study are the following studies that state an effect of antibody formation responses based on gender. Several studies that have been carried out to determine antibody responses in terms of different sexes have found that the male sex has a lower antibody formation response than the female sex (Struve, J et al., 1992; Cardell, 2009; Zimmermann, P et al., 2019; Jabal, KA et al., 2021).

Only a few research have looked at the immunological response to vaccines concerning gender. The immunosuppressive effect of testosterone induces a decreased antibody response to vaccinations in males, mediated via gene expression involved in lipid metabolism and related with inhibition of the inflammatory response (Bouman et al., 2004; Ortona, E et al., 2019).

Women's innate and adaptive immune responses (humoral and cellular) are generally stronger than men's. TCD4+ cells are found in more significant numbers in women than in males, and TCD4+ cells are recognized to play a significant role in antibody production (Bouman et al., 2004; Klein, SL et al., 2016; Fink, AL et al., 2018).

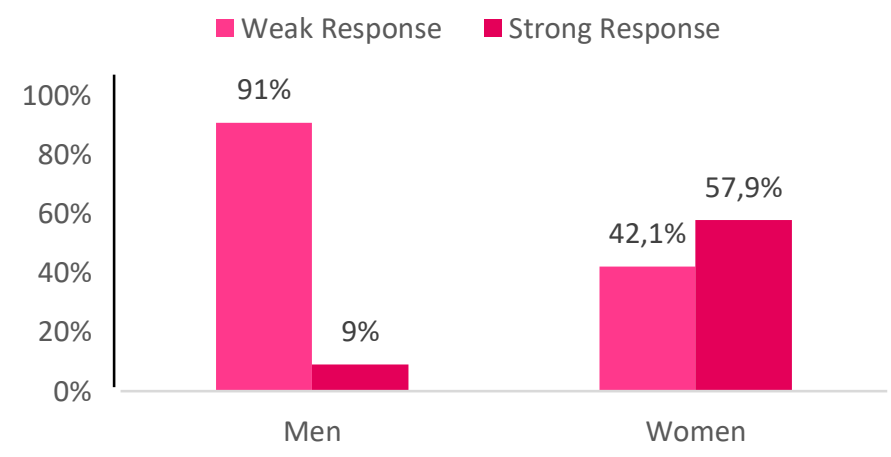

Figure 2. Association of Anti-HBs Antibody Response and Gender

\section{Association of Anti-HBs Antibody Response and Age}

Figure 3 shows that the age range for forming a solid antibody titer is $24-45$ years, while the age range for forming a weak antibody titer is $17-25$ years. This was 20 years ago (or vaccinated as a baby). Even though this age group had been vaccinated as an adult, the percentage of weak and high antibody responses was balanced in the old age group ( $46-65$ years). The results showed a significant value of the relationship between the response to the formation of anti-HBs antibodies and age (table 2). However, this research contradicts the study by Dunn-Walters and Wagner, who examined the effects of aging on humoral and cellular immune responses. The elderly had significantly lower vaccine-specific antibody titers. Lower production of cytokines like interferon-gamma (IFN- $y$ ) correlates with reduced humoral immune response in the elderly (elderly). In the elderly, changes in cellular immunity and reduced antibody titers are particularly noticeable (Dunn-Walters et al., 2003; Wagner et al., 2018). 


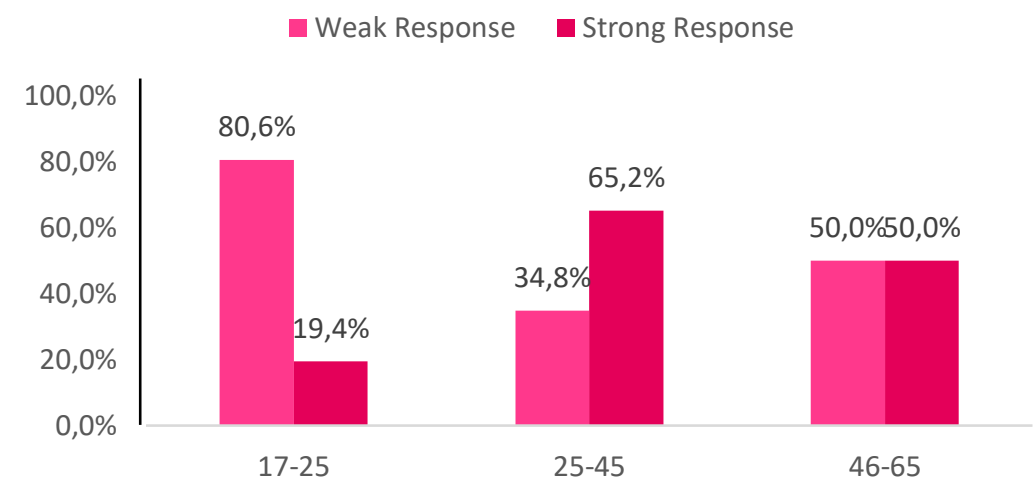

Figure 3. Association of Anti-HBs Antibody Response and Age

\section{Association of Anti-HBs Antibody Response and Ethnic}

The ethnicity data has a non-significant value (P-value $>0.005)$ (table2). The data distribution amongst ethnic groups is not evenly distributed; out of 60 research respondents, 39 are from the Banjar tribe, while the remainder is from diverse ethnic groups in Indonesia. To assess the association between antibody response and ethnicity, limitations in the data distribution must be re-examined and tested utilizing a bigger sample and an even distribution of data.

Previous research has found that the host's genetic factors are responsible for forming a solid or weak antibody response (Wang \& Lin, 2007; Haralambieva et al., 2014; Choe et al., 2020). Furthermore, Wang \& Lin (2007) found that vaccination storage conditions based on geographic location did not affect the value of the antiHBs titer produced.

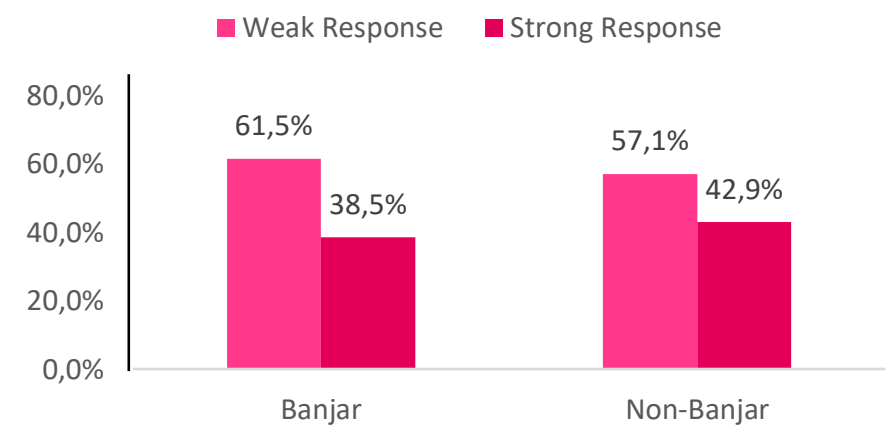

Figure 4. Association of Anti-HBs Antibody Response and Ethnic

\section{Association of Anti-HBs Antibody Response and BMI}

In numerous studies, increased BMI is inversely related to the antibody response to Hepatitis $B$ vaccination. Increased BMI was initially associated with a more robust antibody response after immunization. Higher BMI was associated with a more significant antibody decrease 12 months after vaccination, and obese individuals also exhibited fewer specific TCD8+ cells and less IFN- production, suggesting that $\mathrm{BMI}$ influences vaccine response rate. Furthermore, the decreased vaccination response in obese people may be related to the vaccine's predominant distribution in fat rather than muscle. Enzymatic action can prevent absorption and facilitate denaturation of vaccination antigens. Another possibility is that the proliferation and function of antibody-secreting plasma cells are compromised (Cardell, 2009; Varshochi, M \& Taghizadeh, 2013; Yang et al., 2016). 
In this study, it was not found that Body Mass Index (BMI) affected vaccination outcomes. In contrast, in other studies, it has been shown that BMI (table 2 and figure 5 ), especially $>30$, is associated with lower response rates. This study cannot prove the relationship between $\mathrm{BMI}$ and antibody response because the factors that influence the formation of antibody titers cannot be measured only from obesity. The data found in non-obese respondents as much as $69 \%$ were caused by their BMI but on average non-obese respondents were vaccinated for an extended period of about 10-20 years.

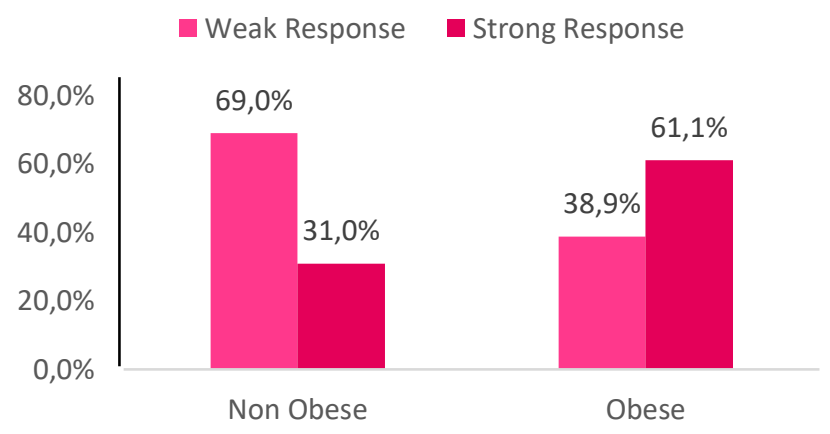

Figure 5. Association of Anti-HBs Antibody Response and BMI

\section{Association of Anti-HBs Antibody Response and Smoking Habit}

Some people who smoke have a poorer antibody response to Hepatitis B immunization. Smoking is closely linked to a low vaccine response rate for Hepatitis B. Smokers' immunoglobulin levels were found to be lower than nonsmokers'. Dendritic cell function is known to be harmed by smoking. Nicotine blocks T-cell antibody-forming cell responses by interfering with antigen-mediated pathways and intracellular calcium responses. Nicotine inhibits dendritic cell antigen absorption and the ability of naive T cells to develop into Th1 cells. In smokers, T cell growth is hampered (Winter et al., 1994; Cardell, 2009; Yang et al., 2016; et al., 2019; Zimmermann, P., 2019).

As shown in table 2 and figure 6, the results showed that seven respondents who had a smoking habit produced low antibody titers. However, statistical analysis did not show a relationship; clinically, the $100 \%$ smokers group of respondents had a weak antibody response. This is very much in line with previous studies.

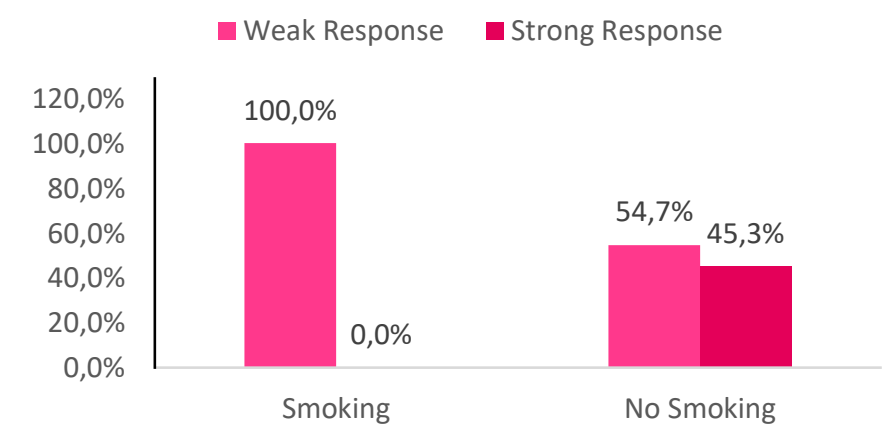

Figure 6. Association of Anti-HBs Antibody Response and Smoking Habit

\section{Association of Anti-HBs Antibody Response and Vaccination Frequency}

Before the second dose of Hepatitis $B$ vaccination, there was a cell-mediated immune response and proliferation in peripheral blood mononuclear cells (PBMC) 
induced by HBsAg and generation of IFN-ץ (2nd dose). The amount of HBsAg-induced PBMC proliferation varies from person to person. In addition, cytokines produced in response to HBsAg stimulation can activate Th1 or Th2 cells (Cardell, 2009; Tripathy et al., 2011; Yang et al., 2016; Zimmermann, P., 2019).

Figure 7 shows that respondents who have just received the first dose of the vaccine have not been able to form high antibody titers, so the second dose of vaccination is necessary. Respondents who had received the second and third doses of vaccination obtained higher antibody titers and were better able to protect against Hepatitis B infection.

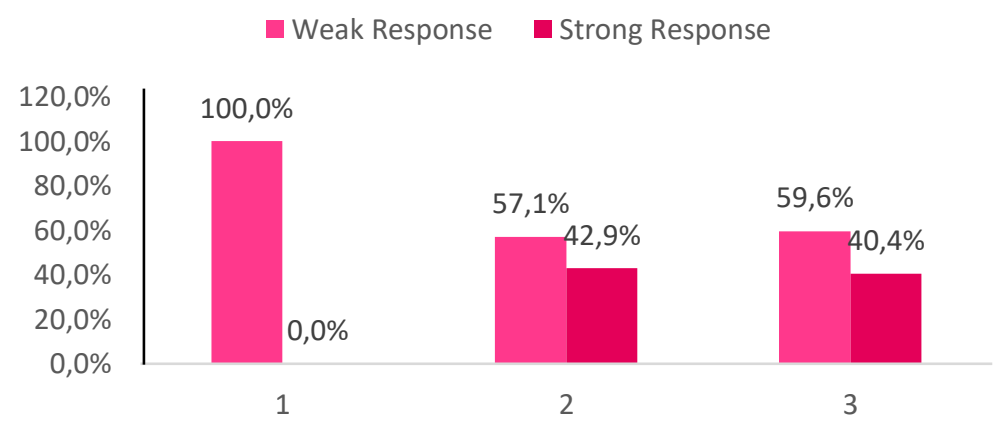

Figure 7. Association of Anti-HBs Antibody Response and Vaccination Frequency

\section{Association of Anti-HBs Antibody Response and Last Vaccination Time}

Anti-HBs antibody levels decline in the years following vaccination, and in some cases, the vaccinated will have anti-HBs levels $<10 \mathrm{mIU} / \mathrm{mL}$ after five years (Zhao $Y$ et al., 2019). Research data shows that respondents who have been vaccinated against Hepatitis B within a period of 10-20 years experience a decrease in anti-HBs titers, while respondents who have been vaccinated for 0-5 years appear to have a weak response because it is influenced by the presence of respondents who have just taken one times the dose vaccinated and some other influenced by smoking habits.

Vaccination has been shown to induce active anti-HBs antibodies accompanied by HBsAg-specific immunological memory, which provides continuous protection in the absence of antibodies. According to Bagheri-Jamebozorgi, M et al. (2014), the persistence of immunological memory for five years after primary vaccination is seen from a rapid increase in antibody levels after booster vaccination, even in subjects who have lost antibodies. The presence of immunological memory in B lymphocyte memory induced during the first exposure to an antigen and upon subsequent exposure to the same antigen induces the rapid production of specific antibodies. In addition, spotELISA assays have shown that the number of memory $B$ lymphocytes capable of producing anti-HBs antibodies does not decrease as antibody levels decrease. In other words, the loss of antibodies does not necessarily mean the loss of immunity to Hepatitis B virus (HBV) antigen due to the presence of immunological memory. Therefore, individuals whose anti-HBs levels drop to $<10 \mathrm{mlU} / \mathrm{mL}$ may not be at risk for liver disease because they have HBsAg-specific immunological memory. After exposure to HBV, the presence of immunological memory rapidly leads to a solid anamnestic response, which prevents acute disease and chronic infection (Banatvala et al., 2000; El-Sayed et al., 2010; Bagheri-Jamebozorgi, M et al., 2014). 


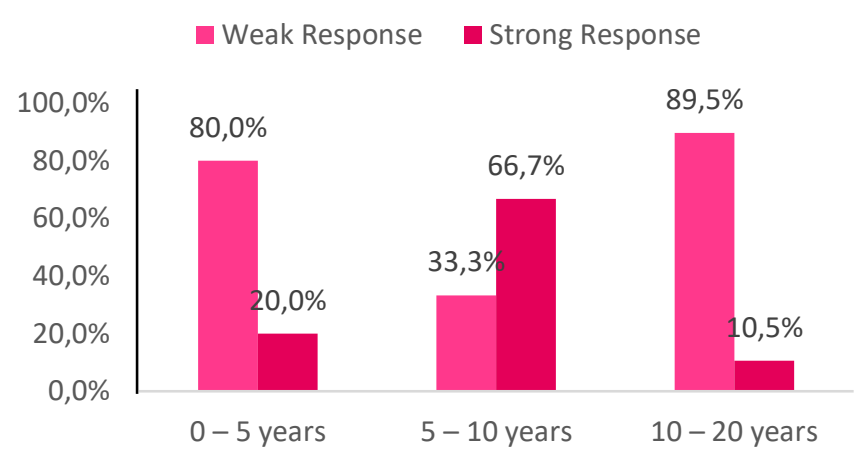

Figure 8. Association of Anti-HBs Antibody Response and Last Vaccination Time

\section{Association of Anti-HBs Antibody Response and Disease History}

Because the pathophysiology of comorbidities is various, people with them frequently have complex and unstable situations. Although some studies have not established a link between comorbidity and seroprotection, comorbidity may be a critical factor that affects the efficiency of the Hepatitis B vaccination, resulting in reduced immunity (immunity). However, the precise mechanism between a poor response to the Hepatitis $B$ vaccine and individuals with comorbidities is still unknown (Yang et al., 2016). In this study, no significant correlation was found between a person's comorbid conditions and the response to the formation of anti-HBs antibodies after vaccination (table 2 and figure 9).

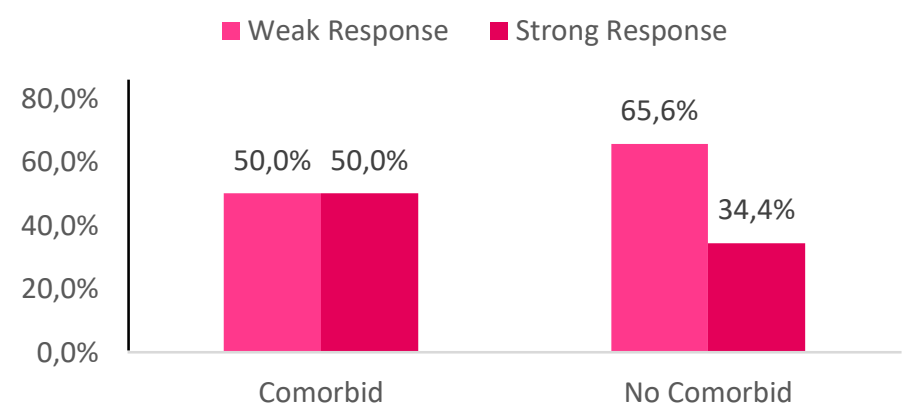

Figure 9. Association of Anti-HBs Antibody Response and Disease History

In this study, there were still limitations in the number of samples that could not represent all the characteristics of the respondents, for example, the types of ethnic groups that were not evenly distributed among the selected respondents, as well as the characteristics of the number of respondents who had been vaccinated with various doses ( $1-3$ times), so that in the following research it is necessary to pay attention to the number of samples proportionally and represent all the characteristics observed in the study.

\section{CONCLUSION}

Health workers who have a weak immune response to the formation of antiHBs antibodies are 36 people (60\%), and robust immune response is 24 people $(40 \%)$. The longer the time from immunization, the vaccine's effectiveness will decrease significantly. Low antibody titers should be revaccinated to enhance anti-HBs titers, and health workers who smoke should quit because it reduces the levels of anti-HBs titers produced clinically. For further research, further molecular studies can be carried 
out to observe the genes that cause a weak response to post-vaccination antibody formation.

\section{ACKNOWLEDGEMENT}

The authors would like to thank all parties involved in this study.

\section{CONFLICT OF INTEREST}

The authors declare that there are no conflicts of interest regarding the publication of this paper.

\section{REFERENCES}

Bahmani, M.K., Khosravi, A., Mobasser, A., Ghezelsofla, E. (2010). Seroprevalence of hepatitis $B$ virus infection and vaccination compliance among health care workers in Fars Province, Iran. Iranian Journal of Clinical Infectious Diseases, 5(1), 45-50.

Bastiangga, D., Hapsari, R. (2019). Profil Imunitas Terhadap Virus Hepatitis B Pada Tenaga Kesehatan Di Rimah Sakit Nasional Diponegoro Semarang. Jurnal Kedokteran Diponegoro, 8(4), 1338-1350.

Bagheri-Jamebozorgi, M., Keshavarz, J., Nemati, M., Mohammadi-Hossainabad, S. and Rezayati, M.T., Nejad-Ghaderi, M., Jamalizadeh, A., Shokri, F., Jafarzadeh, A. (2014) 'The Persistence of Anti-HBs Antibody and Anamnestic Response 20 Years After Primary Vaccination with Recombinant Hepatitis B Vaccine at Infancy. Human Vaccines and Immunotherapeutics, 10(12), 3731-3736. doi: 10.4161/hv.34393.

Banatvala, J., Van Damme, P. and Oehen, S. (2000). Lifelong protection against hepatitis $\mathrm{B}$ : The role of vaccine immunogenicity in immune memory. Vaccine, 19(7-8), 877-885. doi: 10.1016/S0264-410X(00)00224-3.

Bouman, A. et al. (2004). Gender Difference in The Non-Specific and Specific Immune Response in Humans. American Journal of Reproductive Immunology, 52(1), 1926. doi: 10.1111/j.1600-0897.2004.00177.x.

Cahyono, J. S. (2010). Hepatitis B. Yogyakarta: Kanisius.

Cardell, K. (2009). Studies on Hepatitis B Vaccination and Factors Associated with the Vaccine Response Kristina Cardell Division of Infectious Diseases, Department of Clinical and Experimental Medicine Faculty of Health Sciences Linköping University Sweden Linköping 2009.

Chaurasia, R., Jain, A. (2009). Microbiology \& Immunology. 4th Edition. New Delhi: Jaypee Brothers Medical Publishers $(P)$.

Choe, Y. J. et al. (2020). Associations between geographic region and immune response variations to pneumococcal conjugate vaccines in clinical trials: A systematic review and meta-analysis. International Journal of Infectious Diseases, 92, 261-268. doi: 10.1016/j.ijid.2019.12.021.

Dunn-Walters, D. K., Banerjee, M. and Mehr, R. (2003). Effects of age on antibody affinity maturation. Biochemical Society Transactions, 31(2), 447-448. doi: 10.1042/BST0310447.

El-Sayed, B. et al. (2010). Long-term Immunogenicity of Hepatitis B Vaccination in children. Zagazig Journal of Occupational Health and Safety, 2(2),16-28. doi: 10.4314/zjohs.v2i2.49258.

Fink, A.L., Klein, S. (2018). The Evolution of Greater Humoral Immunity in Females Than Males: Implications for Vaccine Efficacy. Curr Opin Physiol, 6, 16-20. doi: 10.1016/j.cophys.2018.03.010.The. 
Haralambieva, I. H. et al. (2014). Associations between race, sex and immune response variations to rubella vaccination in two independent cohorts. Vaccine, 32(17), 1946-1953. doi: 10.1016/j.vaccine.2014.01.090.

Jabal, K. A., Ben-Amram, H., Beiruti, K., Batheesh, Y., Sussan, C., Zarka, S., Edelstein, M. (2021). Impact of Age, Ethnicity, Sex and Prior Infection Status on Immunogenicity Following a Single Dose of the BNT162b2 MRNA COVID-19 Vaccine: Real-world Evidence from Healthcare Workers, Israel, December 2020 to January 2021. Eurosurveillance, 26(6), 1-5. doi: 10.2807/15607917.ES.2021.26.6.2100096.

Kemenkes RI (2015). Peraturan Menteri Kesehatan Republik Indonesia Nomor 53 Tahun 2015. Jakarta.

Kemenkes RI (2019) Profil Kesehatan Indonesia 2018 (Indonesia Health Profile 2018). http://www.depkes.go.id/resources/download/pusdatin/profil-kesehatanindonesia/Data-dan-Informasi_Profil-Kesehatan-Indonesia-2018.pdf.

Klein, S.L., Flanagan, K. (2016). Sex Differences in Immune Responses. Nature Reviews Immunology, 16(10), 626-638. doi: 10.1038/nri.2016.90.

Levinson W. (2014). Medical Microbiology and Immunology. 3th Edition. United States: Mc Graw Hill Education.

Mahawal, B. S. et al. (2013). Estimation of Anti Hbs antibody titer in adults during 510 years period following three doses of vaccine. IOSR Journal of Pharmacy and Biological Sciences, 7(1), 20-23.

Ortona, E., Pierdominici, M. and Rider, V. (2019). Sex Hormones and Gender Differences in Immune Responses, Frontiers in Immunology. doi: 10.3389/9782-88945-936-0.

Pusdatin Kemenkes RI (2017) Situasi Penyakit Hepatitis B di Indonesia, Pusat Data dan Informasi Kementerian Kesehatan RI.

Rao, T. V., Suseela, I. J. and Sathiavathy, K. A. (2008). Estimation of Antibodies to HBsAg in Vaccinated Health Care Workers. Indian Journal of Medical Microbiology, 26(1), 93-94.

Roggendorf, M. and Viazov, S. (2003). Health Care Workers and Hepatitis B. Journal of Hepatology, 39, 89-92. doi: 10.1016/s0168-8278(03)00313-1.

Sahana, H. V., Sarala, N. and Prasad, S. R. (2017). Decrease in Anti-HBs Antibodies Over Time in Medical Students and Healthcare Workers after Hepatitis B Vaccination. BioMed Research International, 2017, 5. doi: $10.1155 / 2017 / 1327492$.

Shouval, D. (2003). Hepatitis B vaccines. Journal of Hepatology, 39(1), 70-76. doi: 10.1016/S0168-8278(03)00152-1.

Struve, J., Aronsson, B., Frenning, B., Granath, F., Sydow, M. V., Weiland, O. (1992). Intramuscular Versus Intradermal Administration of a Recombinant Hepatitis B Vaccine: a Comparison of Response Rates and Analysis of Factors Influencing the Antibody Response. Scandinavian Journal of Infectious Diseases, 24(4), 423-429. doi: 10.3109/00365549209052627.

Sudiono, J. (2014). Sistem Kekebalan Tubuh. Jakarta: EGC.

Tripathy, S. et al. (2011). Study of immune response after hepatitis B vaccination in medical students and healthcare workers. Indian Journal of Preventive and Social Medicine, 42, 315-321.

Varshochi, M., Taghizadeh, S. (2013). Correlation Between Body Mass Index (BMI) and Immunologic Response to Hepatitis B Vaccine. Life Science Journal, 10(1).

Wagner, A., Garner-Spitzer, E., Jasinska, J., Kollaritsch, H., Stiasny, K., Kundi, M., Wiedermann, U. (2018). Age-related differences in humoral and cellular immune 
responses after primary immunisation: Indications for stratified vaccination schedules. Scientific Reports, 8(1), 1-12. doi: 10.1038/s41598-018-28111-8.

Wang, L. Y. and Lin, H. H. (2007). Ethnicity, substance use, and response to booster hepatitis $B$ vaccination in anti-HBs-seronegative adolescents who had received primary infantile vaccination. Journal of Hepatology, 46(6), 1018-1025. doi: 10.1016/j.jhep.2007.01.022.

Winter, A. P. et al. (1994). Influence of smoking on immunological responses to hepatitis B vaccine. Vaccine, 12(9), 771-772. doi: 10.1016/0264410X(94)90283-6.

Yang, S. et al. (2016). Factors Influencing Immunologic Response to Hepatitis B Vaccine in Adults. Scientific Reports, 6, 27251. doi: 10.1038/srep27251.

Yulia, D. (2019). Virus Hepatitis B Ditinjau dari Aspek Laboratorium. Jurnal Kesehatan Andalas, 8, 247-254.

Zhao, Y.L., Han, B.H., Zhang, X.J., Pan, L.L., Zhou, H.S., Gao, Z., et al.(2019). Immune Persistence 17 to 20 Years After Primary Vaccination with Recombination Hepatitis B Vaccine (CHO) and The Effect of Booster Dose Vaccination. BMC Infect Dis, 19(1), 1-7.

Zimmermann, P., Curtin, N. (2019). Factors That Influence the Immune Response to Vaccination. Clinical Microbiology, 32(2).

Zuckerman, J. N. et al. (1997). Immune Response to A New Hepatitis B Vaccine in Healthcare Workers Who Had not Responded to Standard Vaccine: Randomised Double Blind Dose-Response Study. British Medical Journal, 314(7077), 329333. doi: 10.1136/bmj.314.7077.329. 